husbandry in relation to the problem of the shortage of forage, and various others. Finally, the delicate question of emigration is briefly referred to, and reference is made to a suggestion that there might be a large emigration of Italian workers into Latin America. Such emigration should be properly organised so that workers, technicians and directors of industry would find scope for their enterprise and be able to enjoy a full autonomous existence under the apthority of the country receiving them.

\section{Scientific Equipment made in Egypt}

DR. H. E. NúRs, of the Physical Department, Ministry of ${ }^{2}$ lblic Works, Egypt (J. Sci. Instr., 23, 134 ; 194 , has given a brief but interesting aceount of thp 00,930 articles made for the British Army in the departmental workshop during the period Sencember 1940-January 1946. The workshop, of moderate size, normally deals with the repair of scientific instruments and the occasional construction of research apparatus used in the study of the Nile. With machinery loaned by the British Army, the equipment of the workshop was doubled. Other machines for special purposes were improvised out of scrap. Ultimately, there were 120 workmen of all sorts working in a fairly well-equipped workshop. A list, giving the number and description of the articles accepted by the Army, includes sun compasses, protractors and scales, stereoscopes, slide rules, small topls and fuses.

\section{Americafl'Philosophical Society: Year Book for 1945}

The Year Ror for 1945 of the American Philosophical fociet covering the year January 1, 1945Decem 1945, includes as usual the minutes of the mething and of the executive sessions, together wh the reports of standing committees, that on resparch containing classified reports from recipients oN grants. Among these may be mentioned the following: R. N. Jones on factors influencing the ultra-violet absorption spectra of aromatic compounds; E. J. Schremp on the fine-structure pattern of directional cosmic ray intensity; S. Ochoa's studies on respiratory enzymes; W. J. Eversole's investigation of the relation of carbohydrate-deficient diets to the effectiveness of hormones of the adrenal cortex ; H. J. Muller on age in relation to the frequency of spontaneous mutations in Drosophila; S. MeGregor Pady on the biology of Melanosporella; R. Beutner and T. C. Barnes on a general explanation for the therapeutic action of the drugs which act on the nervous system ; R.P. Forster on the effect of general anæsthetics on renal function in the rabbit; I. M. Korr on the relation between tissue metabolism and physiological activity and O. Meyerhoff's studies on intermediary enzymatic reactions of carbohydrate breakdown.

The feature of the report is the appreciation appended to the report of the Committee of the Library, on certain accessions during the year. These include an evaluation of thirty-three unpublished letters from Benjamin Franklin, written during the years 1753-67, by C. Van Doren, who is editing them for publication; a detailed account of the C. W. Peale papers by Mr. C. C. Sellers, and a note by Z. S. Harris on American Indian Iinguistic work and the Boas Collection, which has now been transferred to the Library. Notes by W. E. Lingelbach on Franklin and the Lewis Evans Map of 1749, by F. Harper on proposals for publishing Bartram's "Travels" and by S. Adelman on equipping the Lewis and Clark expedition originated by Thomas Jefferson in 1801 help to give exceptional general interest to this annual volume.

\section{Society for Psychiral Research}

THe Sociefy Psychical Research has issued a pamphlet de ribing its work (31 Tavistock Square, Londo P.1. Pp. 20. 3d.). It is not generally realize that the Society is a scientific society with a rery of more than sixty years work. It originated wh $\mathrm{h}$ a distinguished group of trained thinkers in the University of Cambridge who were interested in the problem of those mental phenomena which appeared to fall outside the recognized laws of mental life. The Society sets out to examine phenomena of this class in a scientific spirit, and hais during its existence collected and sifted evidence for and against : (1) the acquisition of knowledge without the use of the ordinary channels of sense, (2) communications purporting to come from the dead, (3) certain types of physical phenomena alleged to occur in the presence of a particular type of medium. The fact that some phenomena are apparently contradictory of recognized scientific laws is not in itself an adequate reason for thinking them to be unworthy of study. Already a considerable body of research exists concerned with telepathy, clairvoyance, the relation of such conditions to psychotherapy and the problems of survival. Modern methods of statistical analysis have proved of great value in the interpretation and arrangement of data. The Society is not concerned with mere trickery or trivial anecdotal evidence; but aims at trying to understand, in the interests of truth, phenomena which, if eventually proved, will have an important bearing on our concept of personality.

\section{Announcements}

THE British Association has arranged a Conference on London Traffic and the London Plan which will be held at he Institution of Civil Engineers, Great George Stfeet, London, S.W.1, on September 12-13, when experts will speak on the general problems of traffic town planning and architecture, and on the spegal problems of roads, railways, underground ra/ways and travel by air. The Conference will be open free of charge to the public. Further details can be obtained from the office of the British Association at Burlington House, Piccadilly, London, W.1.

THe Fuel Eeonomy Conference of the World Power Conference will be held at The Hague during September 2.10, 1947. During this Conference, an official visit of two days will take place to the Netherlands State Coal Mines at Lutterade. Further information can be obtained from the British National Committee, World Power Conference, 36 Kingsway, London, W.C.2.

The Dunlop Rubber Co. is contributing $£ 350$ net per annuxh for seven years to the Department of Colloid science in the University of Cambridge for researg work on molecular structure. For the past two years the Department has been carrying out research work for the Dunlop Co. on the structure of natural and synthetic rubber molecules, and the changes occurring in vulcanization. The research will continue under the direction of Dr. G. B. B. M. Sutherland. The work under the new scheme will probably also include ultra-violet and ultra-shortwave radio technique. 